\title{
PENGARUH JENIS ARANG HITAM TERHADAP SIFAT MEKANIK KOMPOSIT KARET ALAM PADA VULKANISAT ELASTOMER BANTALAN JEMBATAN
}

\author{
Effect of Carbon Black Types on Mechanical Properties of Natural Rubber Composite \\ for Elastomeric Bridge Bearing Pads Vulcanizate
}

\author{
Adi CIFRIADI, Santi PUSPITASARI*, dan Woro ANDRIANI \\ Pusat Penelitian Karet \\ Jalan Salak Nomor 1 Bogor 16151 Jawa Barat \\ *Email : puspitasari.santi@puslitkaret.co.id
}

Diterima : 24 Januari 2019 / Disetujui : 7 Februari 2019

\begin{abstract}
Elastomeric bridge bearing pads based on natural rubber which are produced by local industry frequently is facing an quality problems in the terms of retention and compression set. The research was aimed to study the effect of carbon black type as reinforcing filler in the manufacture of natural rubber composite for bridge bearing pads. Type of carbon black used consisted of N330 (HAF), N550 (FEF), N774 (SRF-HM-NS), and N990 (MT). The experiment was began with rubber compounding at laboratory scale capacity of $120 \mathrm{~g}$ compound/batch. Rubber compound obtained then being moulded as testing material. Mechanical properties parameter referred to SNI 3967:2013. In accordance of characterization result, it could be understood that the mechanical properties of rubber vulcanizate was highly depending on crosslink density and rubber-filler interaction. Strong interaction was gained from carbon black with small average particle size or wide surface area. Appropriate carbon black as reinforcing filler for production of natural rubber bridge bearing pads were N550, N774, followed with N330.
\end{abstract}

Keywords: Composite; elastomer; filler; mechanical properties; natural rubber

\footnotetext{
Abstrak

Karet bantalan jembatan dan jalan layang berbasis karet alam produksi lokal sering kali mengalami permasalahan kualitas dalam hal ketahanan terhadap pengusangan dan pampatan tetap.
}

Penelitian ini bertujuan untuk mempelajari pengaruh berbagai tipe carbon black sebagai bahan pengisi dalam pembuatan vulkanisat komposit karet alam untuk bantalan jembatan dan jalan layang. Tipe carbon black yang digunakan terdiri atas N330 (HAF), N550 (FEF), N774 (SRF-HM-NS), dan N990 (MT). Percobaan diawali dengan pembuatan kompon karet pada skala laboratorium berkapasitas $120 \mathrm{~g}$ kompon/batch. Kompon karet yang diperoleh kemudian dicetak untuk sampel uji karakterisasi sifat mekanik vulkanisat komposit karet bantalan. Parameter uji mengacu pada SNI 3967:2013. Mengacu pada hasil pengujian diketahui bahwa sifat mekanik vulkanisat komposit karet bantalan jembatan dan jalan layang bergantung pada derajat ikatan silang dan interaksi antara partikel bahan pengisi dengan molekul karet. Interaksi semakin kuat didapatkan dari carbon black yang memiliki ukuran diameter partikel terkecil atau luas permukaan terbesar. Tipe carbon black yang dianggap sesuai untuk komposit karet bantalan jembatan dan jalan layang adalah N550, N774, kemudian N330.

Kata kunci: Bahan pengisi; elastomer; karet alam; komposit; sifat mekanik

\section{PENDAHULUAN}

Konsumsi karet alam terbesar dunia dialokasikan untuk industri ban kendaraan bermotor $(70 \%$ dari total konsumsi karet alam global). Terjadinya perang dagang antara USA dan China turut mempengaruhi kinerja industri ban yang berimbas pada berlebihnya pasokan karet alam. Faktor ini 
berkontribusi terhadap pelemahan harga jual karet alam yang telah berlangsung sejak akhir tahun 2011. Untuk menghadapi kondisi ini Pemerintah Indonesia mulai mengalihkan konsumsi karet alam ke arah penggunaan non ban yaitu sebagai bahan pendukung pembangunan infrastruktur nasional seperti aspal karet, karet bantalan kereta api, dan karet bantalan untuk perletakan jembatan dan jalan layang.

Industri hilir karet bantalan jembatan dan jalan layang patut untuk segera dikembangkan karena memiliki potensi pasar yang sangat luas. Produk karet bantalan untuk perletakan jembatan dan jalan layang telah diusulkan oleh Delegasi Indonesia dalam Rubber-Based Product Working Group - Asean Consultative Committee for Standards and Quality (PWGACCSQ) sebagai produk karet yang akan dibuatkan harmonisasi standar sebagai persyaratan dalam menghadapi dan implementasi pasar bebas ASEAN Economic Community (AEC). Dengan disetujuinya harmonisasi standar maka Pemerintah akan memberlakukan SNI wajib bagi produk lokal maupun impor sehingga dapat meningkatkan daya saing produk karet bantalan lokal, melindungi konsumen terhadap produk berkualitas buruk dan pihak produsen terhadap persaingan usaha tidak sehat.

Produk karet bantalan lokal komersial umumnya terbuat dari jenis karet alam. Namun produsen yang sebagian besar berskala UKM ini tidak mempertimbangkan susunan formulasi kompon karet yang tepat, hanya mengutamakan keuntungan secara ekonomis. Akibatnya banyak produk karet bantalan jembatan dan jalan layang lokal yang mengalami kegagalan mutu karena tidak memenuhi persyaratan standar sesuai SNI 3967:2013. Kegagalan tersebut utamanya pada parameter pampatan tetap, ketahanan ozon, dan ketahanan terhadap pengusangan. Kelemahan ini disebabkan oleh sifat dasar karet alam yang tidak tahan terhadap proses oksidasi termal atau mudah terdekomposisi ketika terpapar oleh oksigen, ozon, dan sinar matahari karena banyak mengandung ikatan rangkap $\mathrm{C}=\mathrm{C}$ dalam rantai molekulnya (Arayapranee \& Rempel, 2009; Kongparakul et al., 2011; Piyaareetham et al., 2013).
Mengacu pada fakta tersebut, kondisi saat ini pimpinan proyek pembangun jalan dan jembatan lebih mempercayai kualitas produk karet bantalan jembatan dan jalan layang impor yang banyak didatangkan dari China dan Malaysia. Produk karet bantalan jembatan dan jalan layang impor yang telah terbukti tahan lama diproduksi menggunakan karet sintetik tipe kloroprena (CR). Karet sintetik jenis kloroprena diketahui memiliki keunggulan berupa ketahanan terhadap ozon dan oksidasi termal yang sangat baik, sehingga sesuai digunakan sebagai base elastomer dalam manufaktur produk karet untuk aplikasi luar ruangan. Karet ini termasuk dalam kategori karet sintetik dengan tingkat konsumsi tertinggi di dunia meskipun diperdagangkan pada harga sebesar USD 7 per Kg.

Riset ini bertujuan untuk mengkaji rancangan formula kompon karet alam untuk pembuatan komposit karet sebagai material penyusun bantalan jembatan dan jalan layang tipe berlapis dengan mengatur berbagai jenis arang hitam (carbon black) sebagai bahan pengisi yang bersifat penguat (reinforcing filler) sekaligus memiliki kompatibilitas yang baik dengan karet alam dibandingkan bahan pengisi jenis silika. Sedangkan jenis bahan pengisi seperti kapur $\left(\mathrm{CaCO}_{3}\right)$ tidak bersifat penguat terhadap komposit karet (extender filler). Bahan pengisi yang bersifat penguat akan meningkatkan sifat kekerasan dan ketahanan sobek vulkanisat karet (Mostafa et al., 2010). Formula kompon karet terbaik dinilai berdasarkan hasil pengujian sifat fisika dan mekanik vulkanisat karet bantalan jembatan dan jalan layang yang memenuhi persyaratan standar SNI 3967:2013. Dengan diperolehnya formula kompon karet alam untuk produk karet bantalan jembatan dan jalan layang maka diharapkan dapat mensubstitusi produk karet bantalan jembatan dan jalan layang impor berbasis karet sintetik tipe kloroprena.

\section{BAHAN DAN METODE}

Penelitian menggunakan bahan baku utama berupa karet alam jenis SIR 20 sebagai elastomer dalam pembuatan vulkanisat karet untuk komposit karet 
bantalan jembatan dan jalan layang. Karet SIR 20 disediakan oleh Koperasi Karyawan INIRO Bogor Jawa Barat. Sementara bahan kimia kompon karet pada spesifikasi teknis seluruhnya diperoleh dari PT. Multi Citra Chemindo Nusa Jakarta. Bahan kimia kompon karet terdiri atas $\mathrm{ZnO}$ dan Asam Stearat sebagai bahan pengaktif, Lilin parafin sebagai antiozonan, Ionol, 6PPD dan TMQ sebagai antioksidan, minyak parafinik sebagai bahan pelunak karet, CBS dan TMTD sebagai bahan pencepat, sulfur sebagai bahan pemvulkanisasi, dan carbon black sebagai bahan pengisi penguat (reinforcing filler). Arang hitam yang digunakan meliputi N220, N330, N550, N774, dan N990. Komposisi karet alam dan bahan kimia dalam pembuatan kompon karet dirinci dalam formula kompon karet yang diuraikan pada Tabel 1. Formula tersebut telah diuji pada kajian pengaruh sistem vulkanisasi (variasi rasio sulfur terhadap bahan pencepat) dengan menggunakan satu jenis arang hitam (CB N220). Sedangkan spesifikasi arang hitam dirangkum dalam Tabel 2.

Prosedur pembuatan vulkanisat karet mengacu pada ASTM D3182-16 dengan tahapan sebagai berikut : karet alam SIR 20 terlebih dahulu dimastikasi dalam mesin giling terbuka hingga menjadi lunak dan plastis. Kemudian ke dalam matriks karet alam yang telah lunak ditambahkan bahan kimia kompon karet dengan urutan sebagai berikut : bahan pengaktif, bahan antiozon dan antioksidasi, rubber processing oil dan bahan pengisi penguat, bahan pencepat dan terakhir bahan pemvulkanisasi. Karet dan bahan kimianya terus digiling hingga terbentuk kompon karet yang homogen. Kompon karet

Tabel 1. Formula kompon karet

Table 1. Rubber compound formula

\begin{tabular}{clc}
\hline No & \multicolumn{1}{c}{$\begin{array}{c}\text { Bahan } \\
\text { Materials }\end{array}$} & $\begin{array}{c}\text { Komposisi } \\
\text { (berat seratus karet, bsk) } \\
\text { Compotition } \\
\text { (per hunderd rubber, phr) }\end{array}$ \\
\hline 1 & Karet alam, SIR 20 & 100 \\
2 & ZnO & 5 \\
3 & Asam Stearat & 2 \\
4 & Lilin parafin & 3 \\
5 & Ionol & 2 \\
6 & 6PPD & 3 \\
7 & TMQ & 2 \\
8 & Arang hitam & 50 \\
9 & Minyak parafinik & 5 \\
10 & CBS & 0,7 \\
11 & TMTD & 0,8 \\
12 & Sulfur & 1 \\
\hline
\end{tabular}

Tabel 2. Spesifikasi arang hitam

Table 2. Specification of carbon black

\begin{tabular}{|c|c|c|c|c|}
\hline $\begin{array}{c}\text { Kode ASTM } \\
\text { ASTM } \\
\text { Designation }\end{array}$ & $\begin{array}{l}\text { Nama } \\
\text { Name }\end{array}$ & $\begin{array}{l}\text { Singkatan } \\
\text { Abbrevation }\end{array}$ & $\begin{array}{l}\text { Diameter rata- } \\
\text { rata partikel } \\
\text { Average particle } \\
\text { diameter } \\
(\mathrm{nm})\end{array}$ & $\begin{array}{c}\text { Luas } \\
\text { permukaan } \\
\text { Nitrogen } \\
\text { surface area } \\
\left(m^{2} / g\right) \\
\end{array}$ \\
\hline N 330 & High Abrasion Furnace & HAF & 31 & 78 \\
\hline N 550 & Fast Extruding Furnace & $\mathrm{FEF}$ & 53 & 39 \\
\hline N 774 & Semi-reinforcing Furnace & SRF-HM-NS & 110 & 30 \\
\hline N 990 & Medium Thermal & MT & 320 & 8 \\
\hline
\end{tabular}


dimaturasi selama kurang lebih 24 jam agar bahan kimia karet semakin terdispersi secara merata di seluruh bagian matriks karet alam. Kompon karet dicuplik sebanyak 50 gram untuk pengujian karakteristik vulkanisasi menggunakan Rheometer MDR Alpha 2000. Sisa kompon karet dicetak menjadi sampel uji dalam Hydraulic press machine pada suhu $150^{\circ} \mathrm{C}$. Parameter pengujian sifat fisika dan mekanik vulkanisat komposit karet untuk bantalan jembatan mengikuti standar mutu sebagaimana tercantum dalam SNI 3967:2013. Parameter tersebut meliputi kekerasan, kuat tarik, perpanjangan putus, pampatan tetap, dan ketahanan ozon. Pengujian sifat mekanik dilakukan sebanyak 3 kali untuk setiap sampel.

Pengujian kekerasan (ASTM D 224005) menggunakan Frank Durometer Shore A. Kuat tarik dan perpanjangan putus (ASTM D 412-06ae2) menggunakan instrumen Tensometer Llyod 2000R. Pengujian ketiga parameter tersebut juga dilakukan pada kondisi pengusangan yang dipercepat pada $70^{\circ} \mathrm{C}$ selama $168 \mathrm{jam}$. Selanjutnya pengujian pampatan tetap dilakukan berdasarkan ASTM D 395-03 pada penekanan 25\% selama 22 jam pada $70^{\circ} \mathrm{C}$. Pengujian ketahanan ozon sesuai ASTM D 1149-07 dilakukan pada konsentrasi ozon sebesar 25 pphm selama 48 jam, 20\% regangan dan pada $37,7^{\circ} \mathrm{C}$.

\section{HASIL DAN PEMBAHASAN}

Sifat fisika dan mekanik komposit karet sangat dipengaruhi oleh derajat ikatan silang yang terbentuk dalam vulkanisat komposit karet tersebut. Ikatan silang antar rantai molekul karet alam yang dijembatani oleh ikatan monosulfida dan disulfida terbentuk pada saat proses vulkanisasi karet alam sehingga dapat diketahui melalui pengujian karakteristik vulkanisasi (Tabel 3). Tingkat derajat ikatan silang dapat diprediksi berdasarkan perbedaan nilai modulus torsi (MH - ML) (Khimi \& Pickering, 2014). Nilai perbedaan modulus torsi tertinggi dihasilkan oleh vulkanisat komposit karet dengan penambahan carbon black N550 diikuti N330, N774, dan N990. Nilai modulus torsi (M90) yang tercapai pada waktu vulkanisasi optimum (tc90) sebanding dengan MH - ML. Dari Tabel 3 terlihat bahwa carbon black N550 menghasilkan derajat ikatan silang tertinggi meskipun memerlukan waktu vulkanisasi optimum terlama dibandingkan dengan jenis carbon black yang lain pada rentang waktu uji karakteristik yang sama (45 menit).

Perbedaan nilai derajat ikatan silang dan parameter karakteristik vulkanisasi yang lain bergantung pada terjadinya interaksi antar molekul karet dengan partikel bahan pengisi (Karaagac et al., 2011). Ukuran diameter partikel dan luas area carbon black menentukan kekuatan interaksi fisik antar karet dan bahan pengisi. Bahan pengisi yang memiliki ukuran diameter partikel kecil akan disertai dengan luas permukaan yang besar sehingga semakin mudah terdispersi secara merata di seluruh bagian matriks karet alam. Keunggulan ini berimbas pada terciptanya efek penguatan yang semakin besar dari bahan pengisi yang digunakan dalam pembuatan komposit karet karena terbentuknya interaksi karet dan partikel bahan pengisi yang kuat (Chuayjuljit et al., 2002; Yasir et al., 2015). Interaksi antara karet dan partikel carbon black merupakan hasil dari ikatan kimia antara permukaan bahan pengisi yang bersifat asam (acidic surface function) dengan sifat basa dari karet alam (natural rubber alkaline moieties) (AlJouthry, 2014).

Tabel 3. Karakteristik vulkanisasi kompon karet bantalan jembatan Table 3. Curing characteristic of rubber compound for bridge bearing pad

\begin{tabular}{cccccccc}
\hline \multirow{2}{*}{$\begin{array}{c}\text { Tipe } \\
\text { Type }\end{array}$} & \multicolumn{7}{c}{ Karakteristik vulkanisasi pada $150^{\circ} \mathrm{C}$ selama 45 menit } \\
\cline { 2 - 8 } & $\mathrm{M}_{\mathrm{H}}$ & $\mathrm{M}_{\mathrm{L}}$ & $\mathrm{M}_{\mathrm{H}}-\mathrm{M}_{\mathrm{L}}$ & $\mathrm{M} 90$ & tc90 & ts2 & CRI \\
\hline CB N330 & 4,08 & 0,18 & 3,90 & 3,69 & 4,43 & 3,11 & 75,76 \\
CB N550 & 4,44 & 0,07 & 4,37 & 4,00 & 8,50 & 5,43 & 32,57 \\
CB N774 & 3,53 & 0,03 & 3,50 & 3,18 & 7,47 & 5,30 & 46,08 \\
CB N990 & 2,81 & 0,03 & 2,78 & 2,53 & 6,45 & 4,37 & 48,08 \\
\hline
\end{tabular}


Nilai kekerasan vulkanisat komposit karet untuk bantalan jembatan pada kondisi sebelum dan setelah pengusangan disajikan pada Gambar 1. Dapat diketahui dari Gambar 1 bahwa vulkanisat yang dibuat dengan penambahan bahan pengisi jenis carbon black N990 tidak dapat memenuhi persyaratan standar SNI 3967:2013 untuk produk karet bantalan jembatan dan jalan layang jenis karet alam dengan Duro 60 . Komposit vulkanisat karet tersebut hanya memiliki nilai kekerasan sebesar 42 Shore A dan 45 Shore A pada kondisi sebelum dan setelah pengusangan (syarat nilai parameter kekerasan dalam SNI 3967:2013 Duro 60 adalah 60 \pm 5 Shore A). Carbon black N990 memiliki ukuran partikel yang besar dan struktur yang rendah sehingga hanya mampu memberikan efek penguatan yang rendah namun resilien yang tinggi (AlJouthry, 2014). Lebih lanjut, carbon black N330, N550 dan N774 pada dosis penambahan yang sama dalam formula kompon karet (50 phr) secara berurutan menghasilkan komposit vulkanisat karet dengan tingkat kekerasan dari yang paling tinggi. Tabel 2 menginformasikan bahwa carbon black N330 memiliki ukuran partikel terkecil (31 $\mathrm{nm})$ dan luas permukaan terbesar $\left(78 \mathrm{~m}^{2} / \mathrm{g}\right)$ dibandingkan jenis carbon black yang lain dalam formula kompon karet. Ukuran partikel carbon black yang kecil membentuk vulkanisat dengan kekerasan yang tinggi. Selain itu, dengan bertambahnya luas permukaan kontak carbon black dengan molekul karet alam akan diikuti dengan peningkatan jumlah molekul karet yang berikatan dengan agregat carbon black sehingga turut meningkatkan derajat ikatan silang dalam vulkanisat komposit karet (Salehi et al., 2016).

Kekerasan seluruh komposit vulkanisat karet bantalan mengalami peningkatan setelah pengusangan (Gambar 1). Selisih nilai kekerasan tersebut masih dalam kisaran yang diizinkan oleh SNI 3967:2013 Duro 60 sebesar 5 poin. Pengusangan dianggap sebagai salah satu proses perlakuan panas karena merupakan fungsi suhu yang berkontribusi terhadap perubahan sifat mekanik dan umur layanan komposit vulkanisat karet (Woo \& Kim, 2006). Pada saat pengusangan terjadi reaksi oksidasi. Oksidasi berjalan karena adanya molekul radikal bebas dalam matriks karet dengan molekul oksigen. Reaksi ini menyebabkan terjadinya pemutusan ikatan rantai molekul karet dan/atau pembentukan ikatan silang lanjut tergantung pada jenis karet yang digunakan. Pada rantai molekul karet alam, mekanisme pemutusan rantai mendahului terjadi pembentukan ikatan silang lanjut yang mengakibatkan karet mengeras dan menjadi rapuh (Martins et al., 2004; Al-Maamori et al., 2014). Fenomena ini juga dapat diamati dari terjadinya penurunan kuat tarik dan perpanjangan putus komposit vulkanisat karet alam pada kondisi setelah pengusangan sebagaimana disajikan pada Gambar 2 dan 3. Pengusangan oksidatif dapat menyebabkan kerusakan pada vulkanisat komposit karet akibat terjadinya penurunan sifat mekanik pada vulkanisat komposit karet tersebut (Salehi et al., 2016).

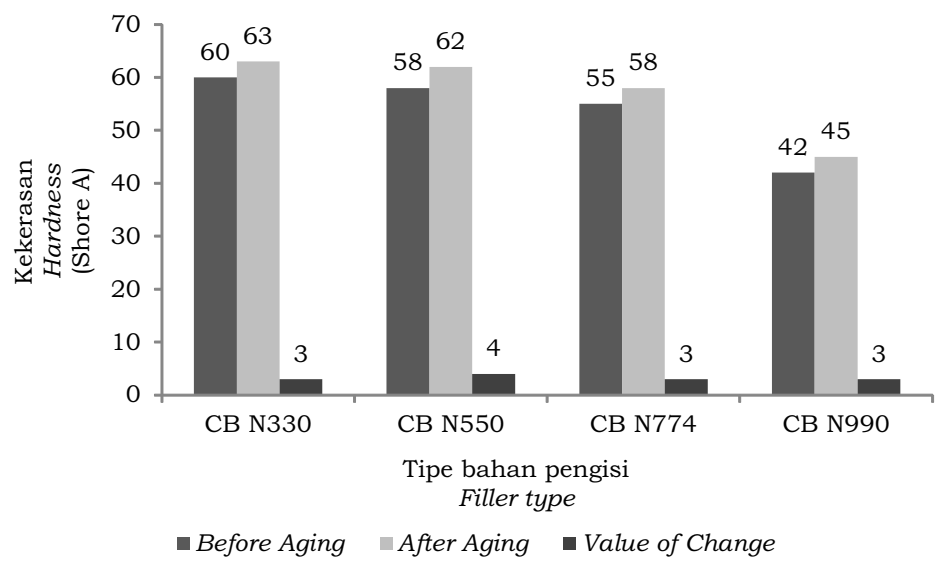

Gambar 1. Nilai kekerasan komposit karet bantalan jembatan

Figure 1. Hardness value of the rubber bearing pad composite 


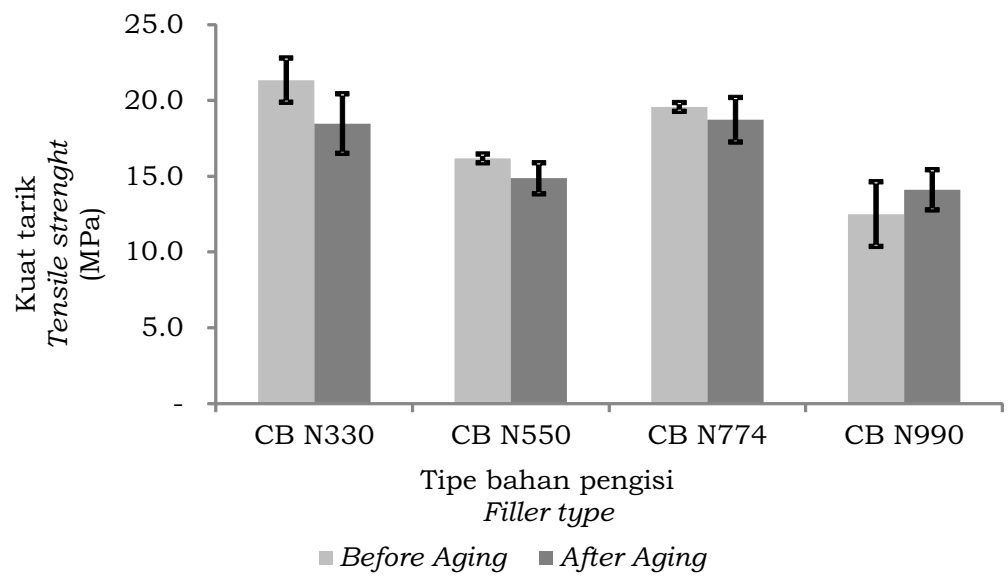

Gambar 2. Nilai kuat tarik komposit karet bantalan jembatan

Figure 2. Tensile strenght value of the rubber bearing pad composite

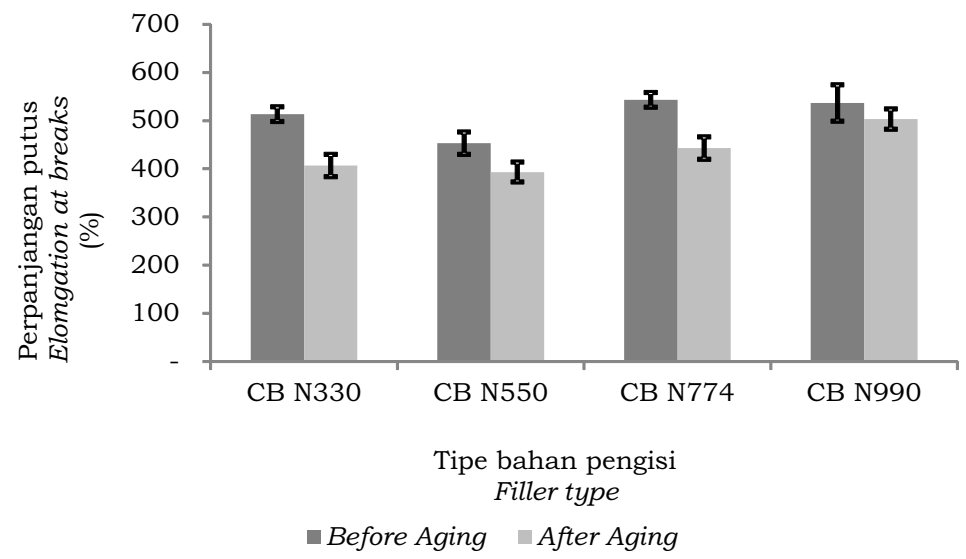

Gambar 3. Nilai perpanjangan putus komposit karet bantalan jembatan

Figure 3. Elongation at breaks value of the rubber bearing pad composite

Dari Gambar 2 dan 3 tampak bahwa carbon black dengan ukuran partikel yang besar cenderung menghasilkan sifat tarik vulkanisat komposit karet yang rendah. Partikel carbon black yang besar akan membentuk agglomerasi berukuran besar akibatnya sulit terdispersi secara merata dalam matriks karet dan hanya menciptakan interaksi yang lemah antara karet dan partikel bahan pengisi. Interaksi fisik antara molekul karet alam dan partikel carbon black berjalan dengan mekanisme gaya Van der Waals (Niedermeier et al., 2002). Sementara, sifat ketahanan pengusangan vulkanisat komposit karet turut dipengaruhi oleh tipe carbon black. Dari Gambar 4. dapat diketahui bahwa carbon black N990 justru memberikan sifat ketahanan pengusangan yang terbaik pada vulkanisat komposit karet alam yang ditunjukan dengan prosentase retensi parameter kuat tarik bernilai positif dan pada parameter perpanjangan putus yang terrendah. Carbon black N990 merupakan jenis thermal black yang umumnya digunakan dalam pembuatan barang jadi karet yang mempersyaratkan ketahanan panas yang unggul (Thompson, 2010). Selanjutnya vulkanisat komposit karet dengan bahan penguat CB N330 tampak memiliki ketahanan pengusangan (retensi) yang rendah. Hasil penelitian Salehi et al. (2016) menemukan bahwa bahan pengisi carbon black yang mempunyai struktur partikel yang rendah cenderung memiliki kestabilan panas yang tinggi begitu pula sebaliknya. 


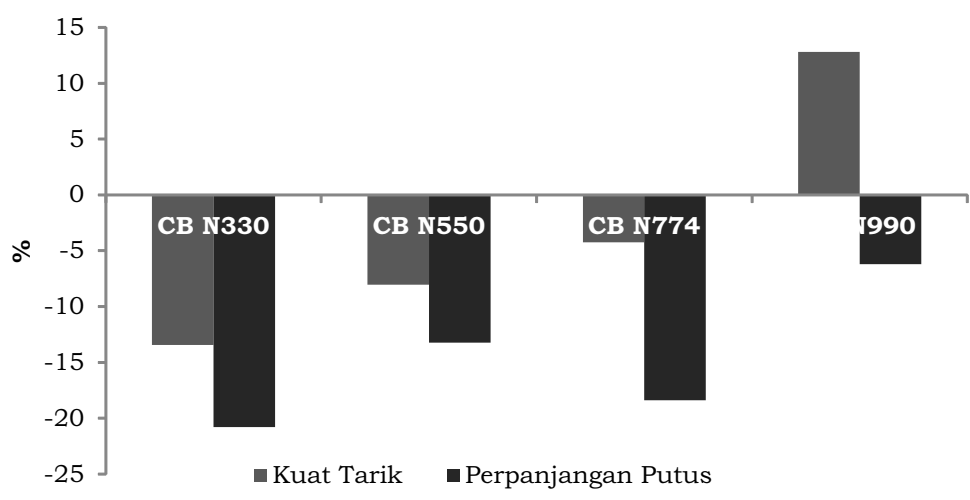

Gambar 4. Ketahanan pengusangan komposit karet bantalan jembatan

Figure 4. Retention of the rubber bearing pad composite

Gambar 5 menyajikan hasil pengukuran pampatan tetap vulkanisat komposit karet dengan penambahan berbagai tipe carbon black. Nilai pampatan tetap yang rendah menjadi syarat mutu produk karet bantalan jembatan dan jalan layang karena akan membentuk sifat elastisitas yang baik. Pampatan tetap dapat didefinisikan sebagai kemampuan elastomer untuk kembali ke bentuk dan dimensi awal setelah tegangan tekan berkepanjangan pada suhu dan defleksi tertentu dihilangkan (Rajan et al., 2012). Dari Gambar 5 terlihat bahwa pampatan tetap terendah diperoleh dari vulkanisat komposit karet dengan penambahan bahan pengisi CB N774, sedangkan CB N550 setara dengan CB N990. Sementara CB N330 menghasilkan pampatan tetap terbesar. Penelitian yang telah dilakukan oleh Cancarb turut membuktikan bahwa nilai pampatan tetap vulkanisat komposit karet dari terkecil hingga terbesar didapatkan dari CB N774 $($ SRF $)<$ N990 $($ MT) $<$ N330 (HAF) <
N550 (FEF) pada dosis penambahan carbon black yang ditetapkan sama pada kompon karet epiklorohidrin. Salah satu sifat unik CB N990 yang dikarakterisasi dengan ukuran partikel yang besar dan struktur yang rendah adalah dapat memberikan sifat pampatan tetap yang rendah pada vulkanisat komposit karet bantalan jembatan dan jalan layang (Thompson, 2010).

Mengacu pada Tabel 4. dapat diketahui bahwa sifat fisik dan mekanik vulkanisat komposit karet bantalan jembatan dan jalan layang yang dibuat dengan menggunakan bahan pengisi arang hitam tipe N550, N774, dan N330 mampu bersaing dengan produk karet bantalan jembatan dan jalan layang komersial yang diperoleh secara impor. Bahkan pada beberapa parameter, vulkanisat komposit karet bantalan jembatan menunjukkan sifat yang lebih baik.

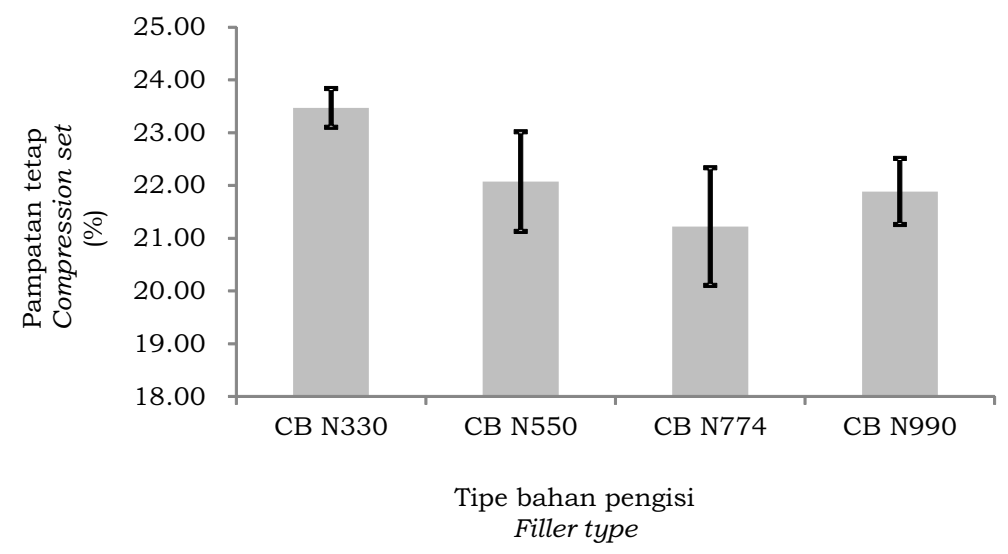

Gambar 5. Nilai pampatan tetap komposit karet bantalan jembatan

Figure 5. Compression set value of the rubber bearing pad composite 
Tabel 4. Komparasi mutu karet bantalan hasil penelitian dengan produk komersial

Table 4. Comparassion of rubber bearing pad quality obtained from the research and its commercial product

\begin{tabular}{|c|c|c|c|c|c|c|}
\hline \multirow{2}{*}{$\begin{array}{l}\text { Parameter } \\
\text { Parameters }\end{array}$} & \multirow{2}{*}{$\begin{array}{l}\text { Satuan } \\
\text { Unit }\end{array}$} & \multirow{2}{*}{$\begin{array}{l}\text { SNI } 3967- \\
2013 \\
\text { Duro } 60\end{array}$} & \multicolumn{4}{|c|}{$\begin{array}{l}\text { Sampel karet bantalan } \\
\text { Rubber bearing samples }\end{array}$} \\
\hline & & & N550 & N774 & N330 & $\begin{array}{l}\text { Komersial }^{*} \\
\text { Commercial }^{2}\end{array}$ \\
\hline Kekerasan & Shore A & $60 \pm 5$ & 58 & 55 & 60 & $56-65$ \\
\hline Kuat tarik min & $\mathrm{MPa}$ & 15,5 & 16 & 19,4 & 21,8 & 15,5 \\
\hline Perpanjangan putus min & $\%$ & 400 & 440 & 540 & 510 & 400 \\
\hline $\begin{array}{l}\text { Perubahan maksimum akibat } \\
\text { pampatan tetap }\end{array}$ & $\%$ & 25 & 22,26 & 20,58 & 23,31 & 30 \\
\hline \multicolumn{7}{|c|}{ Uji pengusangan pada suhu $70^{\circ} \mathrm{C}$, selama 168 jam } \\
\hline Perubahan maks kekerasan & Point & +10 & 4 & 3 & 3 & 10 \\
\hline Perubahan maks kuat tarik & $\%$ & -25 & $-2,56$ & $-4,86$ & $-11,22$ & 15 \\
\hline $\begin{array}{l}\text { Perubahan maks } \\
\text { perpanjangan putus }\end{array}$ & $\%$ & -25 & $-9,09$ & $-20,37$ & $-17,65$ & 20 \\
\hline \multicolumn{7}{|c|}{ Uji ketahanan ozon } \\
\hline $\begin{array}{l}\text { Konsentrasi ozon } 25 \mathrm{pphm} \text {, } \\
\text { waktu uji } 48 \text { jam, regangan } \\
20 \% \text { temperatur } \pm 37,7^{\circ} \mathrm{C} \text {. }\end{array}$ & $\begin{array}{r}\text { No } \\
\text { Tida }\end{array}$ & $\begin{array}{l}\text { rack } \\
\text { retak }\end{array}$ & $\begin{array}{l}\text { Tidak } \\
\text { retak }\end{array}$ & $\begin{array}{l}\text { Tidak } \\
\text { retak }\end{array}$ & $\begin{array}{l}\text { Tidak } \\
\text { retak }\end{array}$ & Tidak retak \\
\hline
\end{tabular}

*Sumber (Source) : Doshin Rubber Engineering, 2019

\section{KESIMPULAN}

Kesimpulan yang dapat ditarik berdasarkan hasil pengujian dan analisis vulkanisat komposit karet adalah sifat mekanik vulkanisat karet, selain dipengaruhi oleh derajat ikatan silang juga turut ditentukan oleh interaksi antara karet dengan bahan pengisi. Partikel bahan pengisi yang berukuran lebih kecil atau luas area yang lebih besar menciptakan interaksi yang kuat dengan molekul karet sehingga memberikan sifat fisik dan mekanik yang unggul bagi vulkanisat komposit karet tersebut, demikian pula sebaliknya. Bahan pengisi arang hitam tipe N990 tidak memenuhi standar mutu sesuai SNI 3967:2013 untuk produk karet bantalan jembatan dan jalan layang Duro 60 karena menghasilkan vulkanisat karet dengan nilai kekerasan 42 Shore A dan kuat tarik 12,5 $\mathrm{MPa}$ pada kondisi sebelum pengusangan, serta 45 Shore A dan 14,1 MPa setelah pengusangan. Bahan pengisi yang dianggap sesuai untuk produk karet bantalan jembatan dan jalan layang adalah arang hitam tipe N550, N774, dan N330 karena mampu memberikan nilai pampatan tetap dan ketahanan pengusangan yang unggul pada komposit karet. Bahkan mutu produk karet bantalan jembatan yang diperoleh dengan menggunakan bahan pengisi tersebut mampu bersaing dengan mutu produk impor karet bantalan jembatan komersial.

\section{UCAPAN TERIMA KASIH}

Seluruh penulis menyampaikan ucapan terima kasih dan penghargaan tinggi kepada Direktorat Jenderal Penguatan Riset dan Pengembangan Kementerian Riset, Teknologi dan Pendidikan Tinggi atas bantuan pendanaan riset yang telah diberikan kepada Pusat Penelitian Karet melalui Program Insentif Sistem Inovasi Nasional (INSINas) Gelombang 1 TA 2018 menurut Kontrak Pelaksanaan Insentif Riset Nomor : 21/INS-1/PPK/E4/2018.

\section{DAFTAR PUSTAKA}

Al-Jouthry, S. A. (2014). The influence surface area and structure of particles carbon black on cure characteristic and mechanical properties of natural rubber. International Journal of Advanced Research in Engineering and Technology, 5(5), 149-159. 
Al-Maamori, M., Al-Nesrawy, S., \& Hasaani, A. (2014). Aging effect on hardness of SBR/NR/BR, SBR/NR composites by using industrial scraps as a filler. Australian Journal of Basic and Applied Sciences, 8(17), 579-584.

Arayapranee, W., \& Rempel, G.L. (2009). Synthesis and mechanical properties of diimide hydrogenated natural rubber vulcanizate. Journal of Applied Polymer Science, 114, 4066-4075. Doi : 10.1002 /app.31132

Cancarb. (........). Technical Bulletin Ephichlorohydrin Compound. Canada: Cancarb.

Chuayjuljit, S., Imvittaya, A., Na-Ranong, N., \& Potiyaraj, P. (2002). Effects of particles size and amount of carbon black and calcium carbonate on curing characteristic and dynamic mechanical properties of natural rubber. Journal of Metals, Materials and Minerals, 12(1), 51-57.

Doshin Rubber Engineering. (2019). Laminated Structural Bearings. Malaysia: Doshin Rubber Engineering.

Ismail, R., Mahadi, Z.A., \& Ishak, I.S. (2018). The effect of carbon black filler to the mechanical properties of natural rubber as base isolation system. IOP Conference Series: Earth and Enviromental Science 140. 10p.

Karaagac, B., Inal, M., \& Deniz, V. (2011). Predictng optimum cure time of rubber compounds by means of ANFIS. Materials and Design, 35, 833-838.

Khimi, R., \& Pickering, K.L. (2014). A new method to predict optimum cure time of rubber compound using dynamic mechanical analysis. Journal of Applied Polymer Science, 131(6), 17p.

Kongparakul, S., Ng, F.T.T., \& Rempel, G.L. (2011). Metathesis hydrogenation of natural rubber latex. Applied Catalysis A: General, 405, 129-136.
Martins, A.F., Visconte, L.L.Y., Schuster, R.H., Boller, F., \& Nunes, R.C.R. (2004). Ageing effect on dynamic and mechanical properties of NR/Cel II Nanocomposites. Raw Materials and Applications, 57(9), 446-451.

Mostafa, A., Abouel-Kasem, A., Bayoumi, M.R., El-Sebaie, G. (2010). Rubberfiller interactions and its effect in rheological and mechanical properties of filled compounds. Journal of Testing and Evaluation, 38(3), 1-13.

Niedermeier, W., Frohlich, J., \& Luginsland, H.D. (2002). Reinforcement mechanism in the rubber matrix by active fillers. Raw Materials and Application, 55, 356-366.

Piya-areetham, P., Prasassarakich, P., \& Rempel, G.L. (2013). Organic solvent free hydrogenation of natural rubber latex and synthetic polyisoprene emulsion catalyzed by water soluble rhodium complexes. Journal of Molecular Catalysis A: Chemical, 372, 151-159. Doi : 10.1016/j.molcata. 2013.02.025

Rajan, R., Varghese, S., \& George, K.E. (2012). Kinetics of peroxide vulcanization of natural rubber. Progress in Rubber, Plastics and Recycling Technology, 28(4), 201-220.

Salehi, M.M., Khalkhali, T., Soleyman, R., \& Barari, M. (2016). Effect of carbon black type on the thermal properties of fluoroelastomer. European Journal of Advances in Engineering and Technology, 3(2), 27-30.

Thompson, B. (2010). Thermax $N 990$ medium thermal black in nitrile rubber compounds. Asia Pasific: Cancarb Limited. 
Woo, C.S., \& Kim, W.D. (2006). Heat aging effects on the material properties and fatique life prediction on vulcanized natural rubber. e-Journal of Soft Materials, 2, 7-12.
Yasir, H.A., Maamori, M.H.A., \& Ali, M. (2015). Effect of carbon black types on curing behaviour of natural rubber. European Journal of Advances in Engineering and Technology, 2(5), 7780. 